\title{
INFORMATION IMPACTOGRAM APPLICATION FOR FAST DETECTION OF TEMPERATURE INSTABILITY ZONE OF A TWO-CHANNEL CERAMIC ROLLER KILN
}

\author{
Darko Krmpotic, Alan Jovic, Franjo Jovic
}

Original scientific paper A fast procedure for determination of instability zone of a two-channel ceramic roller kiln, Siti type, is proposed. The basis for determination of instability zone is the calculation of code identity of final fallout signal and temperature sensor signal from the roller kiln in relevant critical firing zone. The case of product fallout increase above $6 \%$ is used as indicator for procedure application. Code letters for the signals are determined and their respective onedimensional tessellation entropy is calculated. The case of expanded code and entropy congruence can be taken as indicative enough for determination of the firing instability zone from the fallout increase standpoint. The signal s50 temperature zone of two-channel roller kiln was indicated in the period August/September 2009 as responsible for product losses in approximately six consecutive working shifts. Based on the results, a workflow is proposed for the use of the entropy analysis in real-time industrial setting.

Keywords: firing zone; kiln supervision; tessellation entropy; quality control

Primjena informacijskog impaktograma za brzu detekciju zone nestabilnosti temperature dvokanalne keramičke peći

Izvorni znanstveni članak Za dvokanalnu peć firme Siti predložen je postupak brzog određivanja zone nestabilnosti u priproizvodnji keramičkih pločica. Osnova za određivanje zone nestabilnosti jest izračun kodne identičnosti signala kvara i signala senzora temperature dvokanalne peći u odgovarajućem dijelu kritične zone paljenja. Slučaj povećanja škarta iznad $6 \%$ je upotrebljen kao indikator primjene postupka. Određuju se kodni znakovi i računa se jednodimenzionalna teselacijska entropija za te mjerne signale. Slučaj slaganja ekspandiranih kodova i teselacijskog entropijskog iznosa može se smatrati dovoljno indikativnim za određivanje zone proizvodne nestabilnosti s naslova povećanja škarta. U razdoblju praćenja procesa 2009. u mjesecima kolovoz/rujan to je bila zona signala s50 u kanalu dvokanalne peći u trajanju približno šest uzastopnih radnih smjena. Na temelju ovih rezultata, predložen je radni tok za korištenje entropijske analize $\mathrm{u}$ industrijskom postrojenju u stvarnom vremenu.

Ključneriječi: kontrola kvalitete; nadgledanje peći; teselacijska entropija; zona paljenja

\section{Introduction}

Industrial production of ceramic tiles is highly encumbered by energy expenditures, high competition, and inadequate working force. Ceramic industry has been automated and robotized and a rigorous control of raw material and strict quality control (QC) were implemented in order to match the challenge. Product quality is ensured by final quality control that allows $6 \%$ of product fallout before intervening into production $[1 \div 4]$. Raw tile press and two-channel roller kiln are mentioned in literature as main causes of product loss [5]. A detailed analysis of the product fallout on presses has been made and referred to earlier [2]. Thus, the decision to prepare the analysis of the two-channel roller kiln was reasonable from the product loss standpoint.

The correct work of the ceramic plant's highly automated machines depends on quality of input raw material, raw material preparation, provision of energy condition limit, and quality of machine servicing. We will focus the investigation in this work to the determination of instability zone of the maximum temperature region of the two-channel roller kiln as the second main reason for quality decrease of the final product, in order to discover particular ways to potentially increase production quality.

\section{Description of production situation}

Intervention into an automated batch production process is possible only between daily shifts. Thus, any non-obvious error that can happen to production machines would be corrected at the shift-end final control. Product quality control has to take into account this shift-oriented correction of production machines [4]. Using process measurement data at the shift level was a logical decision for supporting the possibility of detection of product quality aberration at specific production machines.

Actual process measurement data of the production machines have shown unusual constancy at shift rate because of adaptive automation set-point mechanisms ingrained into these machines. All the machines were preset to their optimum production values that were showing practically constant measurement values during each shift - values supervised by quality control service. Nevertheless, the product loss was still varying. A decision had to be taken to take a look into the causes for the product loss. The only way to make real fallout detection fast enough was to take each, however small, variance of the measurement value into account at all process measurement places designated as crucial for quality by the QC service.

Press and roller kiln improper behaviour are not the only contributors to fallout percentage variation. Atomizer also contributes to fallout variation because of granulate humidity and granulometry variation. The fallout derailing from these reasons can be partially circumvented by granulate homogenization by ageing, but ageing is uneven, depending on daily granulate demand and technical in-shift clench.

Because of the atomizer, press is fed by granulate that is not always within designated value range. Flash control of technology process quality is also not always a reliable indication of quality and homogeneity of granulate at silo contour. Additional quality improvement is obtained from automatic granulate fed of small press silo, which depends on actual granulate consumption. Such granulate 
is fed to press tool matrix by press filler. Pressing force can be controlled in an efficient manner, but problems with granulate humidity variation and granulometry are practically unsolvable - which can be observed when controlling the pressed raw tile with penetrometer, whereby dissimilarity of granulate particles and humidity causes different penetration measures in central and corner part of the tile. These structural anomalies generate certain micro anomalies manifested just in the roller kiln.

These anomalies are further amplified during tile upper surface enamelling with different type of englobe, enamel and article dependent tools. Tile sorting directly after the kiln process, combined with adjustment of the firing temperatures in kiln, can lead to fallout decrease because of possible more direct process quality control. Storing tiles for delayed sorting disallows immediate intervention into kiln operating temperatures due to short duration of kiln disturbance. However, possibility of fast reaction is important for the overall process productivity.

\section{Description of fallout analysis procedure}

Because of the importance of even the smallest change in process measurement values, we have decided to apply the analysis of the shift evidenced QC signal by using one-dimensional expanded tessellation entropy as exemplified for the case of tile pressing process [2]. By using information pattern obtained from short signal sequence of four measurements, one can observe information about usually uncorrelated process patterns. This type of entropy analysis generates a 27-letter code which quantifies data differences in process signals for consecutive frame slide of four signal measurements. A unique 27-code rule from Tab. 1 ensures both code pattern diversity and entropy amount diversity by using the expression [2]:

$$
\begin{aligned}
& \text { AlphEn }=-\left(\frac{z_{1}+z_{2}}{2 z_{6}} \log _{2} \frac{z_{1}+z_{2}}{2 z_{6}}+\right. \\
& \left.+\sum_{i=2}^{5} \frac{z_{i+1}-z_{i-1}}{2 z_{6}} \log _{2} \frac{z_{i+1}-z_{i-1}}{2 z_{6}}+\frac{z_{6}-z_{5}}{2 z_{6}} \log _{2} \frac{z_{6}-z_{5}}{2 z_{6}}\right),
\end{aligned}
$$

(bit/signal span)

where $Z=\left(z_{1}, z_{2}, z_{3}, z_{4}, z_{5}, z_{6}\right)$ is a sorted 6-tuple $Y=\left(y_{1}, y_{2}, y_{3}, y_{4}, y_{5}, y_{6}\right)$ and

$$
\begin{aligned}
& y_{1}=x_{1}+d_{1,2}=x_{2}, \quad y_{2}=x_{2}+d_{2,3}=x_{3}, \\
& y_{3}=x_{3}+d_{3,4}=x_{4}, \quad y_{4}=y_{3}+d_{1,3}, \\
& y_{5}=y_{4}+d_{2,4}, \quad y_{6}=y_{5}+d_{1,4} .
\end{aligned}
$$

Here, $X=\left(x_{1}, x_{2}, x_{3}, x_{4}\right), x_{i} \in R$ are four consecutive measurement values of each particular process signal and of the QC signal, with $d_{i, j}$ being differences between particular elements $x_{i}$ and $x_{j}$.

The calculated codes from Tab. 1 and corresponding tessellation entropy of each particular signal from the two channel roller kiln can be compared for code and entropy resemblance with the QC signal of the final quality control. Thus, shift dependent patterns of codes and entropies point to possible causal connection of machine failure and output product fallout. The amount of one dimensional tessellation entropy of particular $\Delta$ -

\begin{tabular}{|c|c|c|}
\hline Code & $\begin{array}{l}\text { Consecutive } \\
\text { signal change: } \\
0 \text { : no change } \\
+: \text { increase } \\
\text { - : decrease }\end{array}$ & $\begin{array}{l}\text { The set }(Y) \text { of all signal differences } \\
\text { used for calculation of the expanded } \\
\text { tesselation entropy }\end{array}$ \\
\hline $\mathrm{A}$ & 000 & 0000000 \\
\hline $\mathrm{B}$ & $00+$ & $00+0++$ \\
\hline $\mathrm{C}$ & $00-$ & $00-0--$ \\
\hline $\mathrm{D}$ & $0+0$ & $0+0+++$ \\
\hline $\mathrm{E}$ & $0-0$ & $0-0---$ \\
\hline $\mathrm{F}$ & $0++$ & $0+++++$ \\
\hline $\mathrm{G}$ & $0--$ & $0-\cdots$ \\
\hline $\mathrm{H}$ & $0+-$ & $0+-+00$ \\
\hline I & $0-+$ & $0-+-00$ \\
\hline $\mathrm{J}$ & +00 & $+00+0+$ \\
\hline $\mathrm{K}$ & -00 & $-00-0-$ \\
\hline $\mathrm{L}$ & $+0+$ & $+0++++$ \\
\hline $\mathrm{M}$ & $+0-$ & $+0-+-0$ \\
\hline $\mathrm{N}$ & $-0-$ & $-0----$ \\
\hline $\mathrm{O}$ & $-0+$ & $-0+-+0$ \\
\hline $\mathrm{P}$ & ++0 & $++0+++$ \\
\hline $\mathrm{Q}$ & +-0 & $+-00-0$ \\
\hline $\mathrm{R}$ & --0 & $--0---$ \\
\hline $\mathrm{S}$ & -+0 & $-+00+0$ \\
\hline $\mathrm{T}$ & +++ & ++++++ \\
\hline $\mathrm{U}$ & ++- & $++-+0+$ \\
\hline $\mathrm{V}$ & +-+ & $+-+00+$ \\
\hline W & $+\ldots$ & $+--0--$ \\
\hline $\mathrm{X}$ & --- & $-\cdots----$ \\
\hline $\mathrm{Y}$ & --+ & $--+-0-$ \\
\hline $\mathrm{Z}$ & -+- & $-+-00-$ \\
\hline $\mathrm{AA}$ & -++ & $-++0++$ \\
\hline
\end{tabular}
modulated measurement signal of codes from Tab. 1 is given in [2].

Table 1 Signal coding for three differences referred to starting signal value and for all six mutual differences from expression (2)

\section{Two-channel roller kiln}

We consider two-channel roller kiln, Siti type, which was installed at the KIO Keramika Orahovica factory in Croatia and was under process inspection in the observation period in August and September 2009. The kiln is 77 meters long with 67 meters of the preheating, heating, and cooling zone. Data on preset temperature values, horizontal disposition and sensor code, actual temperatures, errors and operator communication for channel 1 of the two-channel roller kiln and for production of SKY YEL tile dimensions $250 \times 250 \mathrm{~mm}$ are given in Tab. 2. Signals s44 and s45 of the first channel are collected from position $1092 / 1091$ that is at 39,5 meters and signals s46 and s47 from position 1102/1101 that is at 44 meters from the kiln horizontal elongation. Their corresponding signals s 48 and s49 are collected at 39,5 meters in the second channel of the kiln and s50 and s51 at the 44 meters of the second channel of the kiln horizontal elongation. These are the zones of the highest kiln temperature that significantly influence the burning process and ceramic tile quality. Allowed temperature tolerances in maximum zone are typically $5{ }^{\circ} \mathrm{C}$ as shown in the illustrated example in Tab. 2, at positions No. 9 and 10 for sensors encoded as $\mathrm{s} 45$ and s 47 . 
Table 2 Horizontal array of temperature sensors, corresponding temperatures, set values and actual temperatures for ceramic tile type SKY YEL dimensions $250 \times 200 \mathrm{~mm}$; error and operator communication codes; all for channel 1 of the two channel roller kiln Siti

\begin{tabular}{|c|c|c|c|c|c|c|}
\hline $\begin{array}{c}\text { Channel 1, } \\
\text { No. }\end{array}$ & $\begin{array}{c}\text { Horizontal } \\
\text { position, } \mathrm{m}\end{array}$ & $\begin{array}{c}\text { Measurement } \\
\text { sensor, code* }\end{array}$ & $\begin{array}{c}\text { Preset temperature, } \\
{ }^{\circ} \mathrm{C}\end{array}$ & $\begin{array}{c}\text { Measured } \\
\text { temperature, }{ }^{\circ} \mathrm{C}\end{array}$ & $\begin{array}{c}\text { Absolute } \\
\text { error, }{ }^{\circ} \mathrm{C}\end{array}$ & $\begin{array}{c}\text { Signal status, } \\
\text { com } * *\end{array}$ \\
\hline 1. & 6 & 1012 & 370 & 386 & 16 & com \\
\hline 2. & 10,5 & 1022 & 550 & 548 & 2 & $\mathrm{com}$ \\
\hline 3. & 14,5 & 1032 & 740 & 705 & 35 & $\mathrm{com}$ \\
\hline 4. & 18,5 & 1042 & 790 & 743 & 47 & $\mathrm{com}$ \\
\hline 5. & 23 & 1052 & 870 & 797 & 73 & $\mathrm{k} / \mathrm{al}$ \\
\hline 6. & 27,5 & 1062 & 900 & 833 & 67 & $\mathrm{k} / \mathrm{al}$ \\
\hline 7. & 31,5 & 1072 & 950 & 908 & 42 & $\mathrm{k} / \mathrm{al}$ \\
\hline 8. & 36 & 1082 & 1010 & 989 & 21 & com \\
\hline 9. & 39,5 & $\mathrm{~s} 45 / 1092$ & 1109 & 1108 & 1 & com \\
\hline 10. & 44 & $\mathrm{~s} 47 / 1102$ & 1125 & 1124 & 1 & com \\
\hline 11. & 47 & 1112 & 1085 & 1080 & 5 & com \\
\hline 12. & 51,5 & 1122 & 640 & 640 & 0 & com \\
\hline 13. & 55,5 & 1132 & 540 & 547 & 7 & com \\
\hline 14. & 59,5 & 1142 & 460 & 481 & 21 & com \\
\hline 15. & 66 & 1152 & 250 & 310 & 60 & com \\
\hline
\end{tabular}

Table 3 Partial fallout and signal data from two-channel roller kiln for raw tiles from press 9 in the period August and September 2009; $\mathrm{s} 44-\mathrm{s} 51$ are all signals from the critical high temperature zone, given in ${ }^{\circ} \mathrm{C}$; fallout signal is given in percentage of the final quality control data

\begin{tabular}{|c|c|c|c|c|c|c|c|c|}
\hline $\begin{array}{c}\text { Total } \\
\text { fallout, } \%\end{array}$ & $\mathrm{~s} 44,{ }^{\circ} \mathrm{C}$ & $\mathrm{s} 45,{ }^{\circ} \mathrm{C}$ & $\mathrm{s} 46,{ }^{\circ} \mathrm{C}$ & $\mathrm{s} 47,{ }^{\circ} \mathrm{C}$ & $\mathrm{s} 48,{ }^{\circ} \mathrm{C}$ & $\mathrm{s} 49,{ }^{\circ} \mathrm{C}$ & $\mathrm{s} 50,{ }^{\circ} \mathrm{C}$ & $\mathrm{s} 51,{ }^{\circ} \mathrm{C}$ \\
\hline 3,95 & 1162 & 1148 & 1162 & 1148 & 1132 & 1132 & 1132 & 1132 \\
\hline 1,28 & 1162 & 1148 & 1162 & 1148 & 1130 & 1136 & 1130 & 1130 \\
\hline 3,23 & 1162 & 1148 & 1162 & 1148 & 1129 & 1135 & 1120 & 1135 \\
\hline 3,23 & 1162 & 1148 & 1162 & 1148 & 1129 & 1135 & 1120 & 1135 \\
\hline 7,41 & 1162 & 1148 & 1162 & 1148 & 1129 & 1135 & 1129 & 1135 \\
\hline 4,12 & 1165 & 1150 & 1165 & 1150 & 1118 & 1132 & 1118 & 1132 \\
\hline 4,12 & 1165 & 1150 & 1165 & 1150 & 1118 & 1132 & 1118 & 1132 \\
\hline 6,03 & 1165 & 1150 & 1165 & 1150 & 1118 & 1132 & 1118 & 1132 \\
\hline 2,50 & 1160 & 1145 & 1160 & 1145 & 1118 & 1132 & 1118 & 1132 \\
\hline 0,88 & 1160 & 1145 & 1160 & 1145 & 1120 & 1130 & 1120 & 1130 \\
\hline 5,57 & 1160 & 1145 & 1160 & 1145 & 1120 & 1130 & 1120 & 1130 \\
\hline 5,57 & 1160 & 1145 & 1160 & 1145 & 1120 & 1130 & 1120 & 1130 \\
\hline 3,13 & 1160 & 1145 & 1160 & 1145 & 1120 & 1130 & 1120 & 1130 \\
\hline 6,17 & 1162 & 1147 & 1162 & 1147 & 1118 & 1132 & 1118 & 1132 \\
\hline 6,17 & 1162 & 1147 & 1162 & 1147 & 1118 & 1132 & 1118 & 1132 \\
\hline 6,17 & 1162 & 1147 & 1162 & 1147 & 1118 & 1132 & 1118 & 1132 \\
\hline 2,92 & 1162 & 1147 & 1162 & 1147 & 1118 & 1132 & 1118 & 1132 \\
\hline 2,92 & 1162 & 1147 & 1162 & 1147 & 1118 & 1132 & 1118 & 1132 \\
\hline
\end{tabular}

\section{Data from two channel roller kiln}

An excerpt of measurement signal shift reports from two-channel roller kiln for raw tiles from press in the period August and September 2009 is given in Tab. 3.

\section{Impactogram construction}

Code signs and entropy for data from Tab. 3 are calculated according to Tab. 1 and reference [2]. Code signs and entropy of fallout signal are then compared with corresponding temperature signals. Comparison is performed for shift data from presses no. 10, 9, 8, and 5 . A three-level comparison for shift data for tiles from press no. 10 is shown in impactogram in Fig. 1.: white fields are reserved for events with different temperature and fallout code signs, blue for events with the same code sign but different entropy amount and red for the same code sign and close entropy amount. The correspondent data for one-dimensional tessellation entropy are given in Tab. 4.

\begin{tabular}{|c|c|c|c|c|c|c|c|c|c|c|c|c|c|c|c|c|c|c|c|c|c|c|}
\hline Meas: & 1 & 2 & 3 & 4 & 5 & 6 & 7 & 8 & 9 & 10 & 11 & 12 & 13 & 14 & 15 & 16 & 17 & 18 & 19 & 20 & 21 & 22 \\
\hline $\mathrm{s} 44$ & & & & & & & & & & & & & & & & & & & & & & \\
\hline $\mathrm{s} 45$ & & & & & & & & & & & & & & & & & & & & & & \\
\hline $\mathrm{s} 46$ & & & & & & & & & & & & & & & & & & & & & & \\
\hline $\mathrm{s} 47$ & & & & & & & & & & & & & & & & & & & & & & \\
\hline $\mathrm{s} 48$ & & & & & & & & & & & & & & & & & & & & & & \\
\hline $\mathrm{s} 49$ & & & & & & & & & & & & & & & & & & & & & & \\
\hline $\mathrm{s} 50$ & & & & & & & & & & & & & & & & & & & & & & \\
\hline $\mathrm{s} 51$ & & & & & & & & & & & & & & & & & & & & & & \\
\hline Meas: & 1 & 2 & 3 & 4 & 5 & 6 & 7 & 8 & 9 & 10 & 11 & 12 & 13 & 14 & 15 & 16 & 17 & 18 & 19 & 20 & 21 & 22 \\
\hline
\end{tabular}

Figure 1 Impactogram for signals from two-channel roller kiln while burning raw tiles from press 10 - first 22 shifts in August 2009: white fields are depicting events with different temperature and fallout code signs, blue for events with the same code sign but different entropy amount and red for the same code sign and close tessellation entropy amount; shifts with fallout greater than $6 \%$ are depicted in violet 
Table 4 Tessellation entropy for signals from roller kiln and fallout for raw tile press 10 for first 18 shifts. Red marked are matches in entropy values of signal s50 and fallout signal in row/shift 15 and 16

\begin{tabular}{|c|c|c|c|c|c|c|c|c|c|}
\hline & \multicolumn{9}{|c|}{ Signal tessellation entropies normalized for unit signal span (bit/unit span) } \\
\hline $\begin{array}{c}\text { Shift } \\
\text { instance }\end{array}$ & Fallout & s44 & s45 & s46 & s47 & s48 & s49 & s50 & s51 \\
\hline 1. & 0,731 & 0 & 0,731 & 0 & 0,731 & 0 & 0 & 0 & 0 \\
\hline 3. & 1,755 & 0 & 0 & 0 & 0 & 0 & 0 & 0 & 0 \\
\hline 4. & 1,542 & 0,988 & 0,797 & 0,988 & 0,797 & 2,063 & 2,125 & 2,063 & 1,924 \\
\hline 7. & 0,698 & 1,429 & 1,838 & 1,429 & 1,838 & 1,549 & 1,296 & 1,549 & 1,431 \\
\hline 8. & 1,280 & 0,718 & 0,61 & 0,718 & 0,61 & 0,988 & 1,625 & 0,988 & 0,897 \\
\hline 9. & 1,423 & 0,808 & 0,268 & 0,808 & 0,268 & 1,446 & 1,213 & 1,446 & 1,340 \\
\hline 10. & 1,725 & 0,771 & 1,269 & 0,771 & 1,269 & 0,385 & 0,772 & 0,385 & 0,354 \\
\hline 11. & 1,006 & 0,182 & 0,506 & 0,182 & 0,506 & 0,861 & 1,056 & 0,861 & 0,784 \\
\hline 15. & 2,080 & 0 & 0 & 0 & 0 & 0 & 0 & 2,076 & 0 \\
\hline 16. & 0,878 & 0 & 0 & 0 & 0 & 0 & 0 & 0,876 & 0 \\
\hline 17. & 1,017 & 0,860 & 0,881 & 0,860 & 0,881 & 2,804 & 1,546 & 1,678 & 1,168 \\
\hline 18. & 2,109 & 0,376 & 0,385 & 0,376 & 0,385 & 2,425 & 1,431 & 2,425 & 1,093 \\
\hline
\end{tabular}

\section{Investigation results for fallout from roller kiln regarding raw tiles from different presses}

Investigation of fallout from roller kiln regarding raw tiles from different presses is done according to the procedure proposed in [2] and [6] and referred to particular presses, Fig. 2.

Press 5 (Fig. 2a): shift instance 3 was unfavourable with fallout of $6,17 \%$ but not a single kiln signal is in the influence zone. Conclusion: kiln signal after tile from press 5 does not indicate the cause of critical fallout in shift instance 3 .

Press 6: there are no signal shift instances above critical fallout $(6 \%)$.

Press 8 (Fig. 2b): shift instance 2 indicated 6,08\% fallout without a single kiln signal in the influence zone. Conclusion: kiln signal after tile from press 8 does is not indicated as the cause of critical fallout in shift instance 2 .

Press 9 (Fig. 2c):

1) Shift instance 30 was unfavourable with fallout of $7,41 \%$, and shift instance 30 has in the influence zone s50 red and s50 blue indication. Entropy of $H(\mathrm{~s} 50)=1,545$ in shift instance 28 , and fallout entropy $H(\mathrm{QC})=1,569$ in shift instance 28 , respectively 2,044 vs. 1,625 in shift instance 29 . Conclusion: signal s50 in shift instances 28 and 29 is a possible cause of increased fallout.

2) Shift instances from 39 to 41 were unfavourable with fallout of $6,17 \%$. Shift instances from 39 to 41 have in the influence zone: s44 to s47 blue, s49 and s51 blue. Signal entropies at shift instance 38 are: $H(\mathrm{~s} 44)$ $=0,917 ; H(\mathrm{~s} 45)=0,958 ; H(\mathrm{~s} 46)=0,917 ; H(\mathrm{~s} 47)=$ 0,$958 ; H(\mathrm{~s} 49)=1,03$ and $H(\mathrm{~s} 51)=0,798$. Fallout entropy in shift instance 38 is $H(\mathrm{QC})=1,792$ and signal s49 shows a relatively weak concordance with fallout entropy, but still the strongest one compared to the other signal entropies. Conclusion: It is possible that the fallout is caused at several kiln places because of other causes, with the signal s49 being the most influential. Increased fallout was not indicated at other shift instances in the kiln process.

Press 10 (Fig. 1 and Fig. 2d):

1) Shift instances 18 and 19 (Fig. 1) were unfavourable with fallout of $7,41 \%$ with influence zone: s48 blue, s49 blue, s50 red and s51 blue. Signal entropy in instance 15 is $H(\mathrm{~s} 50)=2,076$, and entropy QC at instance $15 H(\mathrm{QC})=2,080$. Signal s50 is a possible place of tile failures exhibiting very close entropy amount.

Signal entropy at instance 16 is $H(\mathrm{~s} 50)=0,876$ and fallout entropy $H(\mathrm{QC})=0,878$. Signal s50 further indicates place of failure. Signal entropy at shift instance 17 is: $H(\mathrm{~s} 50)=1,678$ and $H(\mathrm{QC})=1,017$. The influence of s50 failure place is lowered, but still exists. Signal entropy at time instance 18 is: $H(\mathrm{~s} 48)=$ 2,$425 ; H(249)=1.431, H(\mathrm{~s} 50)=2,425 ; H(\mathrm{~s} 51)=$ 1,093 and $H(\mathrm{QC})=2,109$. Failure place on the side of roller kiln is still at the position s50 and at position s48 as well. Other two failure positions are too far, according to entropy indication. Roller kiln failure is not exhibited any more at shift instance 19 .

2) Shift instance 22 (Fig. 1) was unfavourable with fallout rate of $6,03 \%$, but there was no code indication of the roller kiln signals.

3) Shift instances from 28 to 30 (Fig. 2d) were unfavourable with fallout rate of $6,17 \%$. Shift instances from 28 to 30 indicate closeness of: s44s47, s49 and s51 as blue at shift instance 27. Signal entropies at shift instance 27 are: $H(\mathrm{~s} 44)=0,613$; $H(\mathrm{~s} 45)=0,844 ; H(\mathrm{~s} 46)=0,613 ; H(\mathrm{~s} 47)=0,844$, $H(\mathrm{~s} 49)=1,056$ and $H(\mathrm{~s} 51)=0,784$, and $H(\mathrm{QC})=$ 1,792 .

Conclusion: Although the possible failure impact is exhibited in almost whole maximum temperature zone of both channels of the roller kiln, signals from the kiln are not indicated as the fallout cause because their entropy values are too far from the entropy of the QC signal. 
a) Press 5: first 23 working shifts

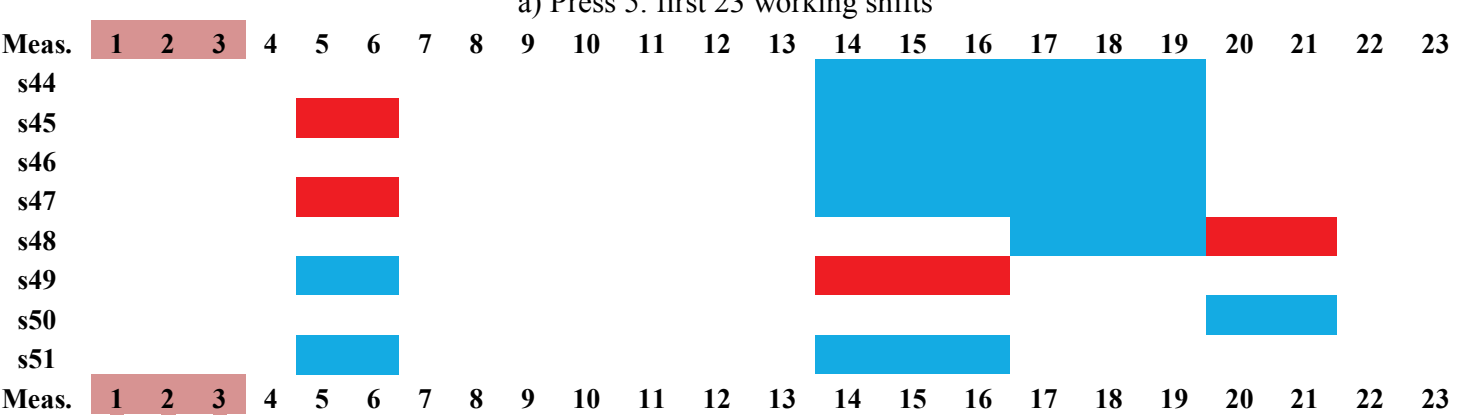

b) Press 8: first 23 working shifts

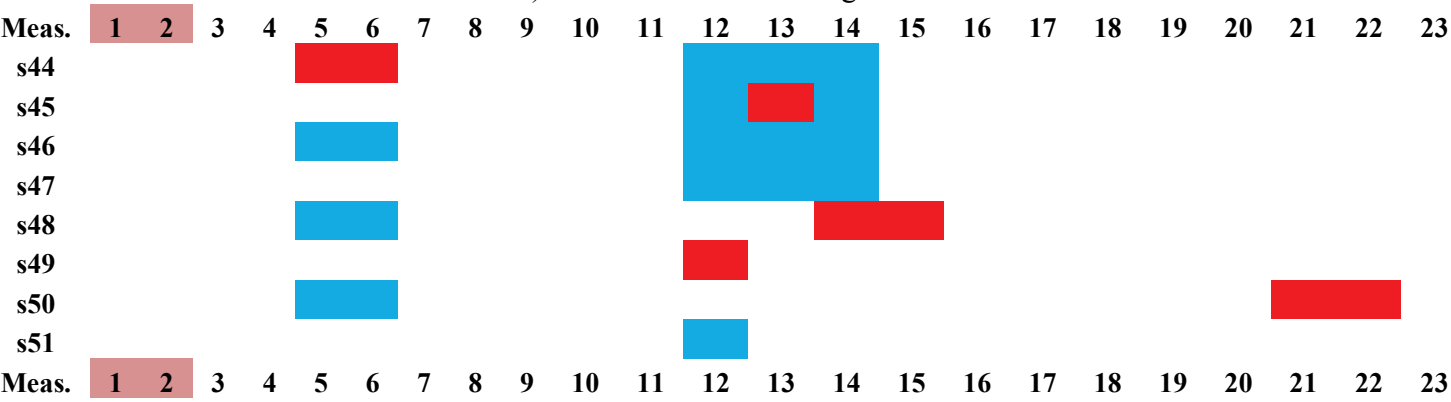

c) Press 9: $24^{\text {th }}$ to $43^{\text {rd }}$ working shift

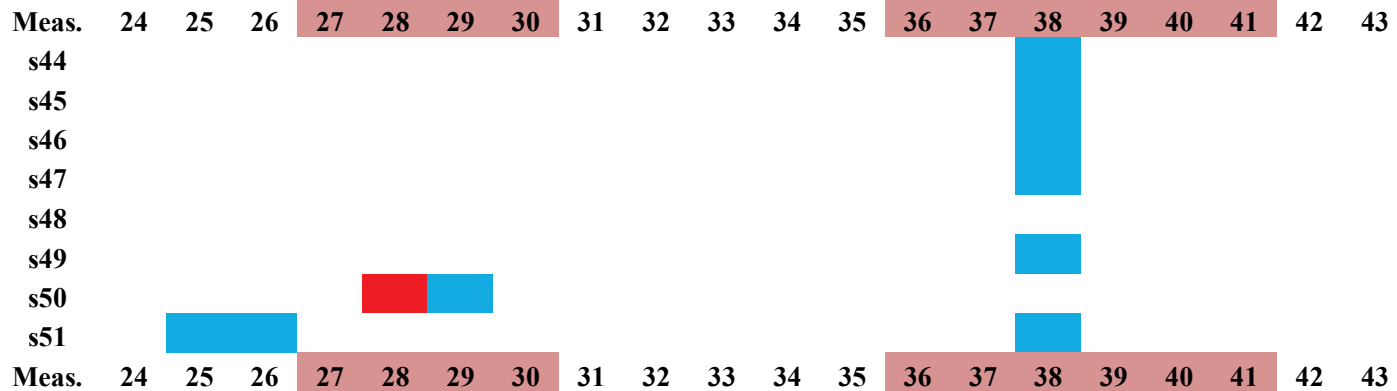

d) Press 10: working shifts 25 to 47

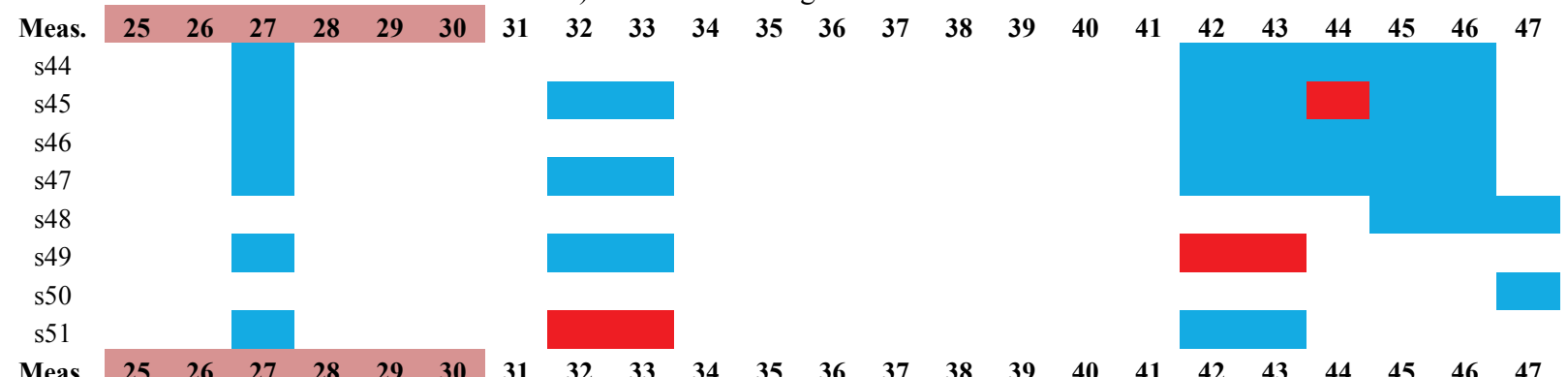

Figure 2 Concordance of fallout code and temperature signal codes from two-channel roller kiln and from several presses in KIO Keramika ceramic tile plant

\section{Discussion about the possibility of impactogram usage in quality control of roller kiln}

\subsection{Feasibility of diagnostics}

Roller kiln is the most critical component in ceramic tile production [5]. It is expected to dominate, together with presses, in fallout contribution. Our above presented results point to production failures at the hottest part of the roller kiln where temperatures are above $1100{ }^{\circ} \mathrm{C}$ or at position of sensor s50 on the roller kiln. Fallout or quality failure at that place happens when temperature falls down by $5{ }^{\circ} \mathrm{C}$ or more. The cause of this failure is discontinuity of power supply, supply voltage drop or failure of roller kiln heaters. Time duration of the failure is about 30 minutes. Calculating with processing speed of $5 \mathrm{~m}^{2}$ of tiles per minute damage can be estimated to $150 \mathrm{~m}^{2}$ with additional $120 \mathrm{~m}^{2}$ of tiles with firing defects because of improper zone temperatures - inducing breakages, cracks, bubbles, and shrinkages [5].

\subsection{The analysis of fallout due to roller kiln}

The main cause of fallout that is induced due to roller kiln are temperature variations referring to the preset firing curve for specific tile type. Main place of fallout was detected at s50 signal zone. Attained signal s50 temperature is between $1120{ }^{\circ} \mathrm{C}$ and $1130{ }^{\circ} \mathrm{C}$ and uncontrolled decrease of the temperature for $5^{\circ} \mathrm{C}$ or more causes fallout and production shutdown. The 
responsibility for fallout is mainly with the roller kiln operator.

\subsection{The prevention of roller kiln failure}

In order to circumvent possible fallout causes of roller kiln or to keep them at the lowest level, at least under $6 \%$, it is necessary:

1) To ensure a stable electric power supply in the sense that roller kiln ought to possess an unintermitted electric power provision. Thus roller kiln should be provided with an alternative electric power generator that can be switched on without interruption to the process in the case of a power supply failure. Still, there is a problem with even short power supply absence during switching phase between generator and power supply and vice versa. Power supply interrupt causes partial dysfunction of roller kiln, resulting in sharp decrease and then sharp increase of the maximum kiln temperature before its stabilization to preset values.

2) To organize periodic plant maintenance with continuous evidence of observed working defects those are the basis for a necessary repair. Repair plan includes a precise time and place of repair type of work, necessary repair specialists and necessary repair material.

3) To educate roller kiln operators by organizing proper theoretical and practical education on the side of plant supplier or from operating crew leaders. Quality manager organizes auditing of operators and, based on the results, issues an internal certificate of achieved education level for operators. Internal audit has to be performed once in a year by checking operator's working habits and follow up of prescribed procedures, working manuals and working standards.

4) To provide the kiln with adequate computer control that is to enable a supervisory control unit that automatically adjusts temperature curve of the kiln, roller speed, and sets alarm in the case of parameter outrun as well as to indicate eventual plant failure, production jam, and to prepare production report.

5) To provide full filling of the kiln in order to enable stable keeping of the temperature curve and better power efficiency of the kiln - change of tile batch can cause certain discontinuity of the kiln filling that is a characteristic feature of shorter product tile series.

6) To control both channels of the kiln in the s50 zone, particularly when fed with raw tiles from press 9 and press 10 in instances when maximum temperature variations occur because of instant voltage drop of the electrical energy or because of network power failure. Operators should be trained for such working situations in order to control electromagnetic gas valves that are automatically shut down with power failure and put them manually into operation. The other case for operator preparation is to intervene in the case where a kiln failure happens and kiln automatically operates in forward-backward regime, thus increasing maximum temperature in critical zone.

\subsection{Possibility of impactogram usage in quality control of ceramic tile production}

Based on the current results, a workflow was proposed for quality control applicable to ceramic tile production based on information impactogram. The workflow is shown in Fig. 3 as an UML activity diagram [7].

Key issue in impactogram application is the acquisition of fallout data, press data, and kiln data on working shift basis. All procedures are initiated by fallout increase to and above $6 \%$. Then, in the case of the code pattern equality between kiln and fallout data and similar signal entropy, an action is taken that checks up all earlier mentioned disturbance causes. The procedure for equal code and similar entropy on press and fallout demands primarily correction of press matrix fixation. Absence of code similarity and thereby absence of entropy similarity demands corrective actions in powder, grain and silo preparation.

\section{Conclusion}

By calculating code equality and entropy similarity between temperature profile signals of the roller kiln and fallout signal, a potentially critical section of the kiln at signal s50 position has been identified from the aspect of charging, kiln manipulating, and electrical power disturbances in the KIO-KeramikaOrahovica plant in a shorter period of six working shifts during August and September 2009. The applied method discovered that the increased fallout cause was not always improper operation of the kiln - the increased fallout was caused by other production processes as well.

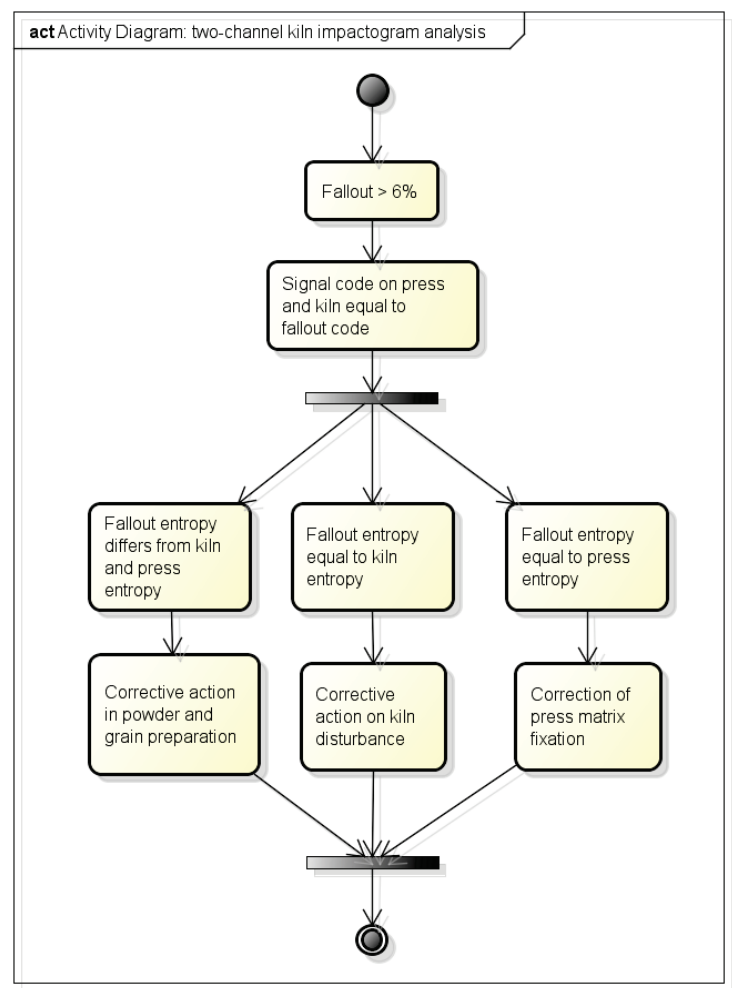

Figure 3 The workflow of using information impactogram that calculates signal codes and entropy content of signals from press and two-channel roller kiln 
Signal position s50 is in the maximum temperature region of the kiln and reasons for observed temperature deviations could have been: short interruption of electric power supply, kiln improper charging, disturbance at the gas flow control valve, temperature sensor failure, and other kiln failures such as exhaust gas ventilation failure, cooling ventilation failure, kiln roller failure, cooling zone failures as well as various less frequent kiln function disturbances.

A simple and fast procedure is proposed for plant staff, where a permanent follow up of signal codes and their tessellation entropy calculations ensures fallout decrease.

\section{References}

[1] Tsarouhas, P. H; Arampatzaki, D. Application of Failure Modes and Effects Analysis (FMEA) of a Ceramic Tiles Manufacturing Plant. // Proceedings of the $1^{\text {st }}$ Int. Conference on Supply Chains / Katerini, Greece, 2010, pp. $1-17$.

[2] Jovic, F.; Jovic, A.; Krmpotic, D. Quality control engineering in automated ceramic tile production using a signal information content approach. // Advanced Engineering Informatics. 27, 1(2013), pp. 93-107. DOI: 10.1016/j.aei.2012.11.007

[3] ISO 13006:1998. Ceramic tiles - Definitions, classification, characteristics and marking.// International Organization for Standardization, Geneva, Switzerland, 1998. http://www.iso.org/iso/catalogue_detail.htm?csnumber $=173$ 2.(30.11.2014.).

[4] Chen, C.-H.; Chong, Y.-T.; Chang, W.; Yan, W. A qualitytime-cost-oriented strategy for product conceptualization. // Advanced Engineering Informatics. 26, 1(2012), pp. 16-25. DOI: 10.1016/j.aei.2011.08.004

[5] SACMI IMOLA Applied Ceramic Technology Volume II, Imola (Bo) Italy: La Mandragoraof Imola s.r.l., 2002.

[6] Jovic, F.; Jovic, A. Kontrola kvalitete automatizirane obročne proizvodnje upotrebom proširene teselacijske entropije procesnih signala. // Croatian patent no. P20110341, published 2013-11-08, The Croatian Intellectual Property Gazette, no. 12/2013, http://www.dziv.hr/hr/glasnik-hgiv/(30.11.2014).

[7] Ben Mahmoud, H.; Ketata, R; Ben Romdhane, T.; Ben Ahmed, S. A Multi-Agent Approach for modeling a Quality Management System with UML Class and Sequence Diagram. // International Journal of Intelligent Computing Research (IJICR). 1, 1/2(2010), pp. 51-59.

\section{Authors' addresses}

Darko Krmpotic, M.Sc.

Kralja Zvonimira 10/IV, HR-33515 Orahovica

E-mail: dkrmpotic5@gmail.com

Alan Jovic, Ph.D.

University of Zagreb, Faculty of Electrical Engineering and Computing

Unska 3, HR-10000 Zagreb, Croatia

E-mail: alan.jovic@fer.hr

Franjo Jovic, Ph.D., Full Prof.

J. J. Strossmayer University of Osijek, Faculty of Electrical Engineering,

Kneza Trpimira 2b HR-31000 Osijek, Croatia

E-mail: franjo.jovic@etfos.hr 